and sarcoma viruses, can probably be transmitted horizontally.

Dr S. Spiegelman (Columbia University) who has little faith in inherited oncogenes, presented evidence which certainly speaks in favour of horizontal transmission. In his studies with identical twins he has found that the leukaemic twin contained particle-related DNA sequences that could not be detected in the leukocytes of his identical healthy sibling. Dr S. Dube (MaxPlanck Institute, Göttingen) suggested that the mechanism of neoplasia could involve somatic hypermutation of vertically transmitted endogenous type $C$ virogenes; if this hypothesis is correct, Dr Spiegelman would have seen no difference between leukaemic and healthy siblings if he had looked at germ line rather than leukocyte DNA.

Work on viral structural proteins is progressing rapidly. Drs Moenning and Hunsmann (Max-Planck Institute, Tübingen) described the purification and characterisation of the major coat protein p30 (molecular weight 30,000 ) and the major envelope glycoprotein gp71 of Friend erythroleukaemia virus. They showed that gp71 must reside in the surface knobs because treatment with bromelin removes both knobs and gp71. Dr M. Strand (Albert Einstein College, New York) reported that she finds an additional glycoprotein, gp69. Each of these proteins contains distinct interspecies antigenic determinants. The gp69/7.1 mixture can induce neutralising antibodies and thus seems to be potentially the most useful antigen for the preparation of vaccines. Dr F. Lilly (Albent Einstein College, New York) showed that gp69/71 is non-coordinately expressed with the p30 protein but appears to be partially linked to sarcoma genes. Dr Vaheri (University of Helsinki) using radioimmunoassay, showed that leukosis-free chicken cells expressed low concentrations of $\mathrm{p} 30$, but after infection the cellular concentration of $\mathrm{p} 30$ went up by $100-1,000$ fold

The nature of the viral genome was actively discussed. It is generally agreed that the genomic RNA is a $70 \mathrm{~S}$ aggregate (molecular weight $10^{7}$ ) of several 30-35S (molecular weight $\sim 3 \times 10^{6}$ ) subunits. Whether the subunits are identical or not has been a major issue. From the extensive genetic and biochemical evidence accumulated by $\mathrm{Dr}$ Vogt (University of Southern California, Los Angeles) and Dr Duesberg (University of California, Berkeley) it seems that the genome of Raus sarcoma virus is polyploid; that is, the subunits are identical. This is supported by the independent findings of Drs Baluda (UCLA), Billeter (University of Zurich) and Dube.

Drs $\mathrm{Wu}$ and Gallo have been studying compounds which affect virus replication and virus-induced transformation and which may therefore have clinical value. $\mathrm{Dr} \mathrm{Wu}$ described the inhibitory effects of rifamycin SV derivatives on proviral formation and cordycepin on virus production at an early post-transcriptional step. Dr Chandra (Frankfurt) reported on the inhibitory effect of thio-polynucleotide homopolymers of cytidylic acid and uridylic acid.

\section{Energy in agriculture}

from N.R. McFarlane

AT a meeting on October 21 held at the Society of Chemical Industry, chemical and mechanical aspects of energy utilisation in agriculture were discussed.

J. J. Landsberg of Long Ashton Research Station pointed out that the conversion of solar energy into useful biomass is an inefficient process. Man's efforts to increase useful biomass in agriculture moreover require considerable energy input in the form of fertilisers (Professor G. W. Cooke of Rothamsted Experimental Station). While other agricultural chemicals such as herbicides are less energetically demanding, requiring similar energy inputs to mechanical weeding methods (Dr M. B. Green of Imperial Chemical Industries) they are also less effective than fertilisers. The link between solar sources of energy and chemical energy was provided in the discussion of the direct use of coal, oil and gas for heating and mechanical operations on the farm and in the glasshouse (G. F. Sheard, Glasshouse Crops Research Institute).

The paper which created most discussion was that of Dr K. L. Blaxter of the Rowett Research Institute, who showed that known world reserves of energy $\left(42 \times 10^{15} \mathrm{MJ}\right)$ are equivalent to but two years of European sunshine! His Table 1 shows that only $11 \%$ of the total plant material harvested in the United Kingdom is 'farm gate' output, destined for human consumption. After processing this primary plant food

Table 1 Biological energetics of agriculture in the United Kingdom

\begin{tabular}{|c|c|c|}
\hline & \multicolumn{2}{|c|}{$\begin{array}{c}\text { Energy } \\
\left(\mathrm{MJ} \times 10^{\ominus} \mathrm{yr}^{-1}\right)\end{array}$} \\
\hline Solar radiation total inciden & & 10,000 \\
\hline Gross primary production & & \\
\hline harvested from plants & & 1,116 \\
\hline Imports of foodstuffs & & 104 \\
\hline $\begin{array}{l}\text { 'Farm gate' output of } \\
\text { crops }\end{array}$ & 119 & \\
\hline $\begin{array}{l}\text { 'Farm gate' output of } \\
\text { animals }\end{array}$ & 94 & \\
\hline Total farm output & & 213 \\
\hline Edible food from crops & 65 & \\
\hline Edible food from animals & 73 & \\
\hline Total edible food & & 137 \\
\hline Energy required by the por & pulation & 241 \\
\hline
\end{tabular}

Table 2 Energy inputs for agriculture in the United Kingdom

\begin{tabular}{lr} 
& $\begin{array}{c}\text { Energy } \\
\text { Fuel }\end{array}$ \\
Fertilisers and lime & 144.5 \\
Agrochemicals & 128.1 \\
Machinery & 1.2 \\
Processing of foodstuffs & 48.8 \\
Transport & 2.1 \\
& 15.7 \\
& Total \\
\hline
\end{tabular}

yields $65 \mathrm{MJ} \times 10^{9} \mathrm{yr}^{-1}$ of energy for human consumption. $70 \%$ of the prime plant output is eaten by farm livestock - a reflection of the importance of the animal sector in British agriculture. Table 2 was also presented by $\mathrm{Dr}$ Blaxter to show the high energy inputs besides solar energy needed to maintain the agricultural output.

Both Professor E. W. Russell (University of Reading) and Dr R. J. Martin of Plant Protection Limited criticised short term economical evaluation of depleting natural resources. The message I received was that true economic value will not be placed upon such items as fossil fuels until it is too late. Even the use of conventional economic evaluation under such circumstances is somewhat suspect.

\section{Immunity and connective tissue}

\section{from A.C. Allison}

THE Fifth Lepetit Colloquium on The Immunological Basis of Connective Tissue Disorders was held in Madrid on November 11-13. M. Mannik (University of Washington) described the self-association of IgG rheumatoid factors to form stable dimers in which one antibody binding site on each molecule reacts with an antigenic determinant on the $F c$ region of the other molecule. The calculated association constant for this dimerisation is remarkably high $\left(10^{10} 1 \mathrm{~mol}^{-1}\right)$. In addition a concentration-dependent aggregation of dimers into tetramers, octamers and higher polymers is observed. The self association of rheumatoid factors may play a part in perpetuating immunologically mediated synovitis. Complexes of IgG and IgM antiglobulins that precipitate in the cold (cryoglobulins) are sometimes associated with renal disease (E. Franklin, New York University) and some patients with systemic lupus erythematosus (SLE) have been found to have idiotypic markers of monoclonal cryoglobulins in their renal lesions (H. Kunkel, Rockefeller University).

Several laboratories have been studying the antibodies against human $T$ and B lymphocytes, some reactive only in 